\title{
LEGAL REFORMS AND THE DEPRIVATION OF LIBERTY IN CHINA
}

Elisa Nesossi, Sarah Biddulph, Susan Trevaskes and Flora Sapio (eds) Routledge (2016)

TABLE OF CONTENTS

Preface

1. Deprivation of Liberty under Scrutiny

Elisa Nesossi, Sarah Biddulph, Flora Sapio and Susan Trevaskes

\section{PART 1: Administrative Detention}

2. What to Make of the Abolition of Re-Education Through Labour? Sarah Biddulph

3. China's Socialization of Administrative Offenders in the Community: An Unrealistic Agenda?

Li Enshen

4. Deprivation of Liberty against One's Will in Mental Health Institutions in Contemporary China Guo Zhiyuan

PART 2: Criminal Justice Reforms and Deprivation of Liberty

5. Residential Surveillance: Evolution of a Janus-Faced Measure Joshua Rosenzweig

6. China's Pre-Trial Detention Centres: Debates and Proposals for Reforms Cheng Lei and Elisa Nesossi 
7. Addressing the 'Hide and Seek' Scandal: Restoring the Legitimacy of Kanshousuo

Nicola Macbean

\section{PART 3: An Assessment of the Field}

8. Framing Imprisonment Studies in China: Ideology, Law and Politics Elisa Nesossi and Susan Trevaskes

9. Western Analyses of Deprivation of Liberty in China Flora Sapio

10. Opportunities and Challenges for Legislative and Institutional Reform of Detention in China Elisa Nesossi, Sarah Biddulph, Flora Sapio and Susan Trevaskes

\section{Index}




\title{
Chapter 1
}

\section{Deprivation of Liberty under Scrutiny. ${ }^{1}$}

\author{
Elisa Nesossi, Sarah Biddulph, Flora Sapio, Susan Trevaskes
}

\section{Introduction}

Since the early 1980s, the People's Republic of China (PRC) has embarked on a dramatic and on-going experiment with legal and institutional reform (gaige). The aim has been the creation of an efficient and modern justice system, responsive to social and economic change and proactive in protecting the Chinese Communist Party's (CCP) hold on political power. This has meant that over approximately three decades, the topic of reform has also served as the thematic cornerstone of academic analyses in the field of Chinese law and justice. While a number of studies have developed conceptual paradigms - the 'rule of law' most notably - to explain trajectories of the expanding 'law’s empire' in China (c.f. Peerenboom 2002; Lubman 2012), others have assessed reformist processes through empirical case studies (c.f Balme and Dowdle 2009; Woo and Gallagher 2012). In this context though, scholarly work on recent changes to the institutions that administer deprivation of liberty has visibly lagged behind.

The circumstances and experience of reform concerning detention and imprisonment ${ }^{2}$. have been both controversial and understudied. Changes in this area of justice

\footnotetext{
${ }^{1}$ A revised version of this chapter has been accepted for publication in China Law and Society Review (2017).
} 
administration have been particularly contentious, as they usually involve strengthening and expanding the powers of police and justice functionaries, with the aim of managing problems resulting from mass movements in population, increasing crime rates, social deviance and, most controversially, political dissent. That issues related to deprivation of liberty have been understudied is perhaps also inescapable. Given their political sensitivity, until very recently institutions of detention and imprisonment have remained mostly cloaked in secrecy. As a result, the scope, significance and the internal dynamics of reforms to these systems have been less well understood than reforms in different areas of Chinese law.

In today's PRC, one of the most important and defining aspects of the various configurations of deprivation of liberty is that they span two separate justice regimes: criminal and administrative. In the criminal justice system, criminal suspects, defendants or convicted criminals may be deprived of their liberty within police stations, pre-trial detention centres (both prior to or following arrest) and prisons; they may also be subject to residential surveillance at their domicile, work units or other locations defined by the public security authorities (Criminal Procedure Law 2012, Articles 72-79). China also has an administrative detention system that runs in parallel with and organisationally separate from the criminal justice system. With few exceptions such as compulsory drug rehabilitation where the justice department is

\footnotetext{
${ }^{2}$ The section 'Use of Terms' of the Body of Principles for the Protection of All Persons under Any Form of Detention or Imprisonment (hereafter Principles on Detention) 1988 sets a standard in the relevant terminology adopted internationally. Accordingly, 'detention’ refers to the condition of 'any person deprived of personal liberty except as a result of conviction for an offence'. 'Imprisonment' indicates the condition of 'any person deprived of personal liberty as a result of conviction for an offence'.
} 
responsible for the administration of detention centres, Chinese institutions of administrative detention are administered primarily by the public security organs. Police operated detention includes: administrative detention (xingzheng juliu), detention for education (shourong jiaoyu), (including coercive testing and treatment for sexually transmitted infections, and coercive treatment such that given to mentally ill suspects or offenders). ${ }^{3}$. Up until the end of 2013, re-education through labour was also part of this system.

Whether for punitive, rehabilitative, or preventative purposes or for putative purposes of education and reform (transformation), the Chinese authorities have considered these institutions crucial to the control and punishment of crime and other unlawful conduct, as well as to the achievement of a modern justice system. For decades, decisions about the duration, nature and scope of detention of China's vast population of criminal suspects, convicted criminals and minor offenders have been linked intimately to social order and its importance in underpinning the smooth progress of economic development. As a result, existing law has been interpreted flexibly and has also been amended to expand the scope of targets to ensure responsiveness to the social and political dislocations that have resulted from rapid economic reform. By extension, both the law and institutions responsible for detention have also been among the most proactive in protecting the Communist Party's hold on power. This has meant that many of those who manage facilities within this institutional behemoth have sought to maintain or even enlarge their already expansive powers. They have done so by emphasising their centrality to the task of maintaining social and political stability through crime control and prevention. Without explicitly acknowledging it,

\footnotetext{
${ }^{3}$ Detention for repatriation (shourong qiansong) was part of the system until 2003, when it was abolished.
} 
they have also increased the profitability of penal production to cope with growing fiscal stresses on detention facilities (Fu 2005a).

Conversely, reformers and others who advocate for stronger limits to be placed on the use of detention powers have argued that circumscribing rather than expanding state authority is conducive, not detrimental, to social and political stability. ${ }^{4}$. They contend that expansive state power, especially the powers given to China's public security organs, discourages the development of procedural justice and a human rights-based system of governance. In their view, justice can and should be realised by changing the longstanding punitive official mindset, by limiting flexibility and discretion in the implementation of the law and by preventing abuses of power. Respect for fairness and justice, they maintain, lies at the heart of social and political stability. They also argue that in China, politically-defined considerations about social order and stability both underpin and preserve the arbitrary powers exercised by the public security and other justice organs, and that these often eclipse legal or social considerations when deciding whether to impose a period of detention, the length of detention or incarceration and the treatment of people who are detained or incarcerated. Wide discretionary powers in this area of justice administration go hand in glove with the lack of both transparency and adequate oversight mechanisms, which invites punitive overreach and discourages prudent procedural justice-based decision-making.

This volume examines the debates that have take place over the last decade on both the expansion and contraction of state powers to detain and incarcerate for preventative and punitive purposes and the processes by which changes in the scope

\footnotetext{
${ }^{4}$ For a discussion of these types of arguments in relation to re-education through labour see Biddulph 2012.
} 
of detention takes place. These debates are in turn located conceptually within the broader discussions about legal and institutional reforms in contemporary China. To locate the specific studies in this volume, this chapter provides an overview of the various facilities that deprive people of their liberty and the reforms that have been developed to modernise the system.

\section{Reforms to Deprivation of Liberty: An Overview}

\section{A Historical Perspective}

In Chinese legal history, deprivation of liberty was not at the heart of the punishment regime. Prior to the eighteenth century, imprisonment (jiujin) was considered subsidiary to other punishments and was not a form of punishment per se. Rather, its main purpose was to confine wrongdoers before trial and those awaiting the execution of their sentence (Alabaster 1899). It was only at the beginning of the twentieth century that Chinese reformers, reflecting upon Western experiences and the role of detention in reforming convicts, began to perceive imprisonment as a possible alternative to harsher forms of physical punishment and started to distinguish between convicted and unconvicted prisoners. China faced many pressures to adopt a system that more closely resembled that of the 'civilised' West and many reforms approximated a gradual Westernisation of the legal and justice systems. In this process, prisons came to be placed at the centre of the Chinese penal system.

Shen Jiaben, appointed Commissioner for the Reform of the Laws (xiuding falü dacheng) in 1902, advocated construction of new model prisons according to international standards, first in major cities and provincial capitals and, thereafter, at 
the county level. Well ahead of his time, Shen stressed the importance of training prison staff, the promulgation of detailed prisons rules and the collection of statistical data about criminality. He contended that different kinds of offenders should be jailed in different prisons and criminal suspects needed to be treated separately from convicts. Moreover, he pointed out that witnesses, as persons assisting in the administration of justice, should not be imprisoned, as was the practice of the time (T’ao 1966, 275-290; Guo 2005). Though highly controversial, Shen’s proposals led to the promulgation of the first two sets of rules concerning pre-trial detention centres (28 January 1913) and prisons (1 December 1913). These remained in force with few modifications or additions until 1949 (Dikötter 2002, 67). New rules on pre-trial detention centres and county prisons were subsequently passed in May 1919 (Commission on Extra-Territoriality in China, 1926; Dikötter 2002, 3). In the early 1930s in areas under their control, the Chinese communists created pre-trial detention centres and reform through labour institutions (laodong ganhua yuan) to deal with criminal suspects, offenders and, in particular, counterrevolutionaries (fan gemin) (Zhang 2005, 18-19).

Between the establishment of the PRC in 1949 and the 1980s, the concept of 'reform through labour' (laodong gaizao) was used to refer to the reform of detainees convicted of a criminal offence, unconvicted detainees, juvenile delinquents, and Chinese citizens found travelling without documents (Dutton 2005, 353). Prisons, detention centres and reform through labour institutions - the facilities within which targets of reform through labour were held - were under the jurisdiction of the Ministry of Justice (MoJ) until 1950, when they were transferred to the Ministry of 
Public Security (MPS). ${ }^{5}$. The administration of reform through labour camps was regulated under the terms of the Regulations for Reform through Labour (Laodong Gaizao Tiaoli) $1954^{6}$. which continued in force until 1994, ${ }^{7}$. when the PRC's first Prison Law (Jianyu Fa) came into effect.. ${ }^{8}$

\footnotetext{
${ }^{5}$ These changes were introduced by two internal documents, both of which were issued in 1950: the Ministry of Justice and the Ministry of Public Security Decision on Prisons, Reform through Labour Team, Detention Centres (Guanyu Jianyu, Laodong Gaizao Dui He Kanshousuo de Jueding) and the Instructions for the Transferring of Prisons, Detention Centres and Reform through Labour Team to the Ministry of Public Security (Guanyu Jianyu, Kanshousuo, He Ladong Gaizao Dui Yizhuanggui Gong'an Bumen Lingdao De Zhishi) (Dutton 2005, 353). As noted by Dutton, the passage of places of detention from the control of the Ministry of Justice to the Ministry of Public Security initiated a struggle between these two branches of the Chinese government that partially resolved only in 1983 when the Ministry of Justice regained control over the prison system.
}

${ }^{6}$ A partial translation of the text of the 1954 Regulations may be found in Cohen (1968, 365$68)$.

${ }^{7}$ According to a 1979 resolution by the NPC Standing Committee, all laws and regulations enacted after 1949 were to remain effective if not in conflict with the Constitution and other laws or regulations(see NPC Standing Committee Resolution on the Problem of the Legal Effectiveness of Laws and Decrees Enacted Since the Establishment of the People's Republic of China (Quangguo Renmin Daibiao Dahui Changwu Weiyuanhui guanyu Zhonghua Renmin Gongheguo Yilai Zhiding Falü, Faling Xiaoli Wenti De Jueyi) 1979).

${ }^{8}$ The Regulations on Reform through Labour were lastly abrogated by the State Council Resolution on Repealing Some Administrative Regulations Issued Before the End Of the Year 2000 (Guowuyuan Guanyu Feizhi 2000nian De Yiqian Fabude Bufen Xingzheng Faguide Jueding), adopted on and effective from 6 October 2001. 
From 1951, the power of re-education through labour evolved as a pragmatic and flexible response to the state's perceived need to deal with certain categories of people who were politically unreliable or socially undesirable but whose offences were not considered sufficiently serious to warrant the full force of a criminal sanction (Ma 2001, 33). Throughout its existence, re-education through labour (RETL) was conceptually twinned with reform through labour (liang lao). The former was used to detain people whose transgressions were adjudged not to warrant criminal prosecution and the latter to detain people convicted of a crime through the criminal justice system.

On 25 August 1955, the CCP Central Committee issued the Directive on Thorough Elimination of Hidden Counterrevolutionaries (Guanyu Chedi Suqing Ancang De Fangeming Fenzi De Zhishi) providing that 'those people who cannot be convicted of a criminal offence and politically who cannot continue to be used, where returning them to society would increase unemployment, in principle they can be sent to re-education through labour.' The targets of RETL were expanded again in the NPC Standing Committee Resolution on the Decision of the State Council on the Question of ReEducation Through Labour (Quanguo Rendahui Changweiyuanhui Pizhun 'Guowuyuan Guanyu Laodong Jiaoyang Wenti De Jueding’ De Jianyi) 1957 to punish habitual offenders and those whose conduct was deemed morally unacceptable in the new socialist society, such as prostitution, gambling, using narcotic drugs, kidnapping and selling women and children and harmful conduct labelled 'feudal superstition'.

Since the 1980 s

Administrative and criminal systems of deprivation of liberty 
Since adoption of the open door and economic modernisation policies at the end of the 1970s, various forms of deprivation of liberty have been classified as belonging either to the criminal or the administrative system, however the two systems are complementary in nature and design. In the context of the criminal justice system, post-conviction detention has served the purpose of crime control and the punishment of criminal offenders on the basis of the Criminal Law (Xing Fa) 1979 and its subsequent amendments. The Criminal Procedure Law (CPL) (Xingshi Susong Fa) introduced in 1979, significantly revised in 1996 and again in 2012 - provides the basic guidelines for implementing the Criminal Law. Most notably it defines procedures, time-limits and the agencies responsible for carrying out pre-trial procedures. It sets out a number of coercive measures (qiangzhi cuoshi) that may be used to restrain the freedom of action of criminal suspects. It also provides for post arrest detention and imprisonment following conviction. Pre-trial coercive measures include: coercive summons (juchuan), 'taking a guarantee and awaiting trial’ (qubao houshen), supervised residence (also translated as residential surveillance) (jianshi juzhu), pre-arrest detention (juliu) and arrest (daibu). Each of these coercive measures involves restriction or deprivation of personal liberty. In mid-2013, there were 1,701,344 sentenced prisoners (Ministry of Justice 22 December 2014) and approximately 3,250,000 pre-trial detainees (Star News 9 March 2015).

Administrative detention, at least in theory, is intended for minor offenders. It is administered primarily by the public security authorities and the rules and regulations that frame its operation are designed to limit the physical liberty of those who commit 'unlawful' acts such as prostitution, drug use or dependence and other types of misconduct that do not reach the threshold of criminality. Due to its broad scope, administrative offences are divided into four large categories: public order detention 
(regulated by the Security Administrative Punishments Law (Zhi'an Guanli Chufa Fa) 2006 (amended in 2012) which targets minor offenders, detention for compulsory rehabilitation of drug dependent people, detention of sex workers and their clients and, until 28 December, 2013, re-education through labour (NPC Standing Committee Decision on Repealing Legal Rules on Re-Education Through Labour (Guanyu Feichu Laodong Jiaoyang Falü Guiding De Jueding) 28 December 2013).

RETL was revived and expanded after the end of the Cultural Revolution. The December 1979 State Council, Notice Promulgating the 'Temporary Regulations of the Ministry of Public Security on Re-Education Through Labour' (Guowuyuan Zhuanfa Gong'an Bu 'Laodong Jiaoyang Shixing Banfa') defined the scope of targets to cover conduct deemed anti-socialist, conduct harming social order, vice and petty crime. After introduction of the open door and economic reform policy, the targets of RETL were increased incrementally to cover newly emerging forms of socially disruptive or unlawful conduct. Over time, RETL became a useful tool for cleaning the streets of vagrants and beggars (Biddulph 2007). The most notable expansion was in the population of drug dependent people detained in RETL. Repeat and nuisance petitioning, petty theft, fraud, and other conduct considered anti-socialist or anti-Party could conveniently fall within the amorphous bounds of RETL. The scope of RETL evolved and expanded to respond to social order challenges to policing thrown up by the rapidly changing social and economic environment. It was a particularly useful and flexible tool in policing dissent and disruptive rights-asserting conduct. For example, during the crackdown on Falungong in the 1990s, a large number of practitioners were sent to RETL for refusing to give up the practice (Human Rights Watch 2002). From the late 2000s, repeat petitioners, people involved in mass protests, groups targeted because of religious beliefs and practices, such as Tibetans and Uyghurs, 
could often be sent to a term of RETL (Fu 2005b, 828). Re-education through labour was also a convenient way to punish people who criticised Party and government leaders and whose conduct was construed as opposing the state but fell short of the criminal offence of harming national security. From the late 1980s, the largest increase in people sent to RETL was drug users and drug dependent people (Biddulph and Xie 2011). The Regulations on Public Security Organs Handling Re-Education Through Labour Cases (Gong'an Jiguan Banli Laodong Jiaoyang Anjian Guiding) issued on 1 June 2002 by the Ministry of Public Security was the last consolidation of targets of RETL, though the scope of targets continued to be expanded on an ad hoc basis after that.

RETL proved to be a useful backstop for police where legal reforms in other areas restricted police investigation and interrogation powers. It was used to enable investigation to continue where there is insufficient time or evidence to proceed with a criminal prosecution, particularly after the police power to detain and interrogate criminal suspects under detention for investigation (shourong shencha) was abolished in 1996 (Fu 2005a; Biddulph 2007, 195-206). RETL was useful to state agencies because of its flexibility, precisely the characteristic that brought it into conflict with the developing legal system and which made it an anathema to the rule of law principles of transparency, accountability and predictability. Ultimately, it was a power that could not be adequately reformed or retained and, as such, was abolished on 28 December 2013.

Trajectories of reforms

Debates on reform or lack thereof have dominated the literature on detention and deprivation of liberty. Since 1979, when scholars talk about reforms in this field, they 
refer mainly to either legislative or institutional changes. Policy changes have occurred less commonly, though adoption of the criminal justice policy of balancing leniency and severity marked a significant retreat from the overwhelming emphasis on severe punishment of the 'hard strike' policy that had been in place since the early 1980s. Institutional and legislative changes have entailed expansion of administrative power in some areas, increasingly detailed specification of mandatory procedural requirements in exercising powers and development of oversight mechanisms. Debates about the need for and shape of reform in both the criminal or administrative systems of punishment and detention in China are carried out within and between different Party and state agencies including legislative bodies, courts, police, prosecution, justice departments and prisons, and among functionaries within these individual organs. Sometimes these internal discussions amount to little more than attempts to increase institutional power and resources, between the public security and justice institutions, each hoping to maintain or increase their institutional influence. As legal system reform has progressed and as the use of new media has expanded, it has become increasingly possible for others to participate in these debates, from academics and public intellectuals, to citizens interested in and affected by the way these institutions of incarceration work.

However, notwithstanding the increasing participation of the wider community in discussions and debates about reforms and abuses of power, the CCP (both itself and through state enforcement agencies) retains close control over penal policy in China. The implementation of the law and changes in the justice system are subject to the dominance of a political party which frames its justice policies around the control of forces and individuals that may threaten social stability and harm the Party's legitimacy and hold on power. 
Whilst we need to be mindful of the dominance of Party policy, it is equally important to understand that the complex interactions between political and institutional players as well as the increasing plurality of voices outside state institutions have an important role in legal and institutional change. Change is no longer simply a product of topdown directives from the centre of power. Today, legislative and institutional reform can result from political opportunities taken by functionaries in the justice system and from shifting coalitions formed around particular issues, sometimes reacting to openings and sometimes responding to tensions at the central institutional levels of political authority. When discursive space opens up, institutional players at the provincial or local levels advocate for change by aligning themselves with current policies and priorities particularly those aimed at containing social disorder and maintaining social and political stability.

Compared to the immediate post-Mao period of the 1980s, in more recent times, reforms - or at least the key debates about the imperative to reform - have increasingly come to be informed by wider social forces and opinions. They have broadened to include scholars, NGOs and the general public, and have been facilitated through both the traditional and social media. In fact, over the last decade, the interest and impact of more inclusive societal debates concerning law and justice indicate just how disparate are understandings of the concepts of reform and justice among the broad community of practitioners, scholars and those who participate across China's social and traditional media. This diversity reveals changes in social values and in state-society relationships and, more specifically, in the institutional powers to control and contain socio-political problems.

The factors that have driven legislative reforms to various forms of detention over recent years vary in nature and scope. Drafting the 1996 amendments to the Criminal 
Procedure Law 1979 was one key catalyst for reformist debates. Abolition of the administrative investigative power of detention for investigation and its incorporation into the coercive powers contained in the CPL was one. The case of pre-trial detention is also emblematic in this context. Indeed, both in the process of drafting and in the years that followed the enactment of the 1996 amendments, the issue of reforming pre-trial detention became more a focus of Chinese legal scholars, lawyers and members of the procuratorate who began to challenge its pervasiveness, the strict link existing between arrest and detention, the abuses of the system of residential surveillance and the monopoly over exercise of these powers by the public security authorities. These voices gradually began to articulate more clearly the view that the various measures used to deprive citizens of their personal liberty constituted serious violations of individual rights and freedom (Chen 2005; Chen 2004; Sun 2007).

Building on domestic discontent over aspects of the CPL 1996 and its implementation, the international community has also sought to shape debates about reform. In the mid-2000s, international civil society groups started to implement projects targeting pre-trial detention centres and prisons in an attempt to improve detainees' conditions of detention and enhance supervision of such institutions. In December 2004, the UN Working Group on Arbitrary Detention and, one year later, the Special Rapporteur on Torture and other Cruel, Inhuman or Degrading Treatment or Punishment, after their respective visits to China, both reported that the rules of criminal procedure and practice concerning pre-trial detention in the PRC did not conform to international laws on human rights. They also found that the period for holding criminal suspects in police custody without judicial supervision was too long both in law and practice. Hence, they recommended the restriction of the pre-trial 
detention period and the extension of non-custodial measures, especially for nonviolent, minor or less serious crimes.

As explained in the following section, changes to the system of residential surveillance offer another example of reforms that have been driven by public discomfort with the expansive powers granted to the public security authorities in the CPL. Residential surveillance is one among the various coercive measures that are justified on the grounds they guarantee the smooth running of criminal proceedings, 'to prevent suspects from interfering with an investigation or continuing in criminal activities’ (Song 2007, 11). Reforms only emerged after intense power negotiations that result in an acceptable compromise among the gongjianfa (the police, the procuratorate and the courts) authorities.

In a similar trajectory of reform, recent changes to the system of administrative detention and punishment have come about as a result of coalescence of a number of political and social forces. There has been longstanding discomfort in legal and scholarly circles - both within and outside China - with the wide discretionary powers given to police to administer administrative punishment in dealing with public order infringements. It has been a matter of serious concern that public security authorities alone could make decisions affecting the lives and fate of millions of people who have not been convicted of a crime but who find themselves incarcerated administratively for stretches of time up to three years.

The most criticised of these powers was RETL. RETL had been the object of strong public feelings for quite a long time and legislative work with a view to reforming it had been on going since at least the 1980s. Debates about reforms of administrative detention have developed at various stages. In the 1980s and 1990s, discussions were 
strictly limited to internally circulated (neibu) public security publications. After the mid-1990s, administrative detention in general, and RETL in particular, came to be a widely debated topic both within China and internationally. The argument was that RETL was unconstitutional, abusive and extra-legal in nature. Severe and chronic abuses documented by lawyers, NGOs and international human rights organisations added weight to these criticisms. Finally, in 2012 the spectacular injustice delivered to Tang Hui when she was sentenced to 18 months RETL for her persistent petitioning galvanised public opinion and ire.. ${ }^{9}$ This case coincided with the strengthening resolve at top political levels to abandon proposals to reform and retain RETL, and instead to abolish it.

The abolition of RETL in December 2013 has been one of the most dramatic changes to the Chinese justice system in recent years and has come about largely as a result not only of media pressure and sustained domestic and international criticism, but also as a result of political jousting at the highest levels of Party power. At the time when China's media denounced widespread abuses of power and exposed cases of people incarcerated for politically-motivated reasons, RETL became caught up in the politics surrounding the stability maintenance (weihu wending, often shortened in weiwen)

\footnotetext{
${ }^{9}$ The mother of an underage rape victim, Tang, protested outside local government buildings, claiming that police had falsified evidence in order to mitigate the punishment of men who had kidnapped and raped her 11 year old daughter, forcing her into prostitution. In August 2012, the police sentenced Tang to 18 months' detention at a RETL facility in Yongzhou, Hunan province, for 'seriously disturbing social order and exerting a negative impact on society’. A public outcry helped secure her speedy release. In April 2013, the Yongzhou court rejected Tang's claim for compensation but in July she won her case on appeal and was compensated RMB 2,941.
} 
program. With the political downfall of Zhou Yongkang and with the general failure of the Hu Jintao and Zhou Yongkang-led stability maintenance program (which ran from 2007 to 2012), the Xi Jinping leadership strategically used the abolition of RETL to draw a line in the sand between the new and the previous Party leadership's stance on stability maintenance.

\section{An Outline of Reform Measures}

\section{Reforming Administrative Detention}

Reform pressure was not limited to RETL. From the 1990s pressure began to build to reform other administrative detention powers including police powers to detain sex workers and their clients and drug dependent people. The minimum common denominator behind the decision to start legislative and institutional reform of RETL and other administrative detention measures, can be found in the existence of inefficiencies and systemic abuses in the employment of these detention measures. Possibly the best known example was the power to detain for repatriation people who came to cities without proper authorisation or documentation. The police were authorised to send these people to detention centres operated by the civil affairs departments, called detention for repatriation stations (shourong qiansong zhan). Systemic abuses of this power, coupled with dangerous conditions within the detention centres culminated in a public scandal (the beating death of a young migrant worker named Sun Zhigang) which precipitated the abolition of this power.

In the case of RETL, 'inefficiencies' consisted not only in the abuses that were widely discussed by the domestic and international press, but also in some structural features. 
From the 1990s there was a surge in the number of people detained in RETL and with the system unable to appropriately respond, this failure prompted its reform and eventual abolition.

As we explained above, RETL was developed largely to manage political dissent and punish minor offences. The occurrence of several crime waves throughout the 1980s and the 1990s led to the adoption of a piecemeal policing strategy based on anti-crime campaigns, which resulted in a gradual and constant multiplication of the targets of RETL. Even though RETL came to include behaviours ranging from ticket scalping to gambling and membership in political and religious groups established outside of the state's control, the main rationale behind it remained unchanged until the early 1990s (Biddulph 2007). The 1980s and the 1990s had however seen a steady growth of the sex trade, as well as of problems of drug dependency (Jeffreys 2004; Gao 21 July 2011).

The policing of the sex trade took place through the revival of measures substantively and procedurally very similar to those introduced four decades earlier, in the 1950s. After a series of rather ineffectual attempts at bringing the sex trade under control, in 1991 the National People’s Congress Standing Committee Decision on Strictly Prohibiting Prostitution and Using Prostitutes (Guanyu Yanjin Maiyin Piaochang de Jueding) consolidated all previous regulatory documents and mandated the use of detention for education and RETL on recidivist prostitutes and their clients (Jeffreys 2004, Biddulph 2007). In practice, police prefer to impose a fine under the terms of the Security Administrative Punishments Law 2006 (amended in 2012) as imposition of detention is costly in terms of time and police resources. The rate at which people involved in the sex trade are detained under either detention for investigation or RETL is influenced by policy imperatives, targeted campaigns at times of moral panic and 
the availability of detention facilities locally. Administrative detention and RETL in particular were not designed to provide any real form of education, medical care or vocational rehabilitation to sex workers. Reliance on police fines was entirely a more convenient enforcement option.

The policing of drug dependent people underwent a reform trajectory not dissimilar to that of policing the sex trade. While voluntary drug treatment had been an option available to drug users since the 1950s, in 1990 the National People's Congress Standing Committee Decision on Prohibiting Drugs (Guanyu Jindu de Jueding) reintroduced mandatory registration at public security bureaus, administrative detention on public security charges, compulsory drug rehabilitation (qiangzhi jiedu) and drug rehabilitation in RETL (Article 8). Compulsory drug rehabilitation in detention centres operated by the police could last between three and six months, and be extended to a year if necessary (State Council Measures on Compulsory Drug Rehabilitation (Qiangzhi Jiedu Banfa) 1995. Drug dependent people who relapsed after release from compulsory drug rehabilitation could receive a term of compulsory rehabilitation through labour at a RETL facility lasting from a minimum of one to three years with a possible extension of a further year for a maximum of four years (Measures on Compulsory Drug Rehabilitation 1995, Article 8). The 1990 National People’s Congress Standing Committee Decision on Prohibiting Drugs led to profound changes both in the structure of the RETL system and in the regulatory and legislative framework on drug use.

Drug users were a population whose needs were different from and more complex than those of minor offenders, sex workers and their clients. Whilst police-run drug rehabilitation facilities in theory contained only drug dependent people, in some RETL facilities drug dependent people were detained alongside other detainees. 
Overcrowded and under-regulated, by the late 2000s drug rehabilitation facilities had outnumber RETL camps. The number of registered addicts, too, had largely surpassed that of RETL detainees (Sapio 2010). The haste with which rehabilitation facilities were set up meant that many of them were fairly small in scale, and sometimes incapable of providing adequate treatment, either due to a lack of sufficient funding or qualified personnel. Many were insecure and endangered the health and safety of detainees (Biddulph 2007). Between 1990 and 2007, nearly three million drug users transited through the compulsory rehabilitation system and, as admitted by Chinese experts, well over 85 per cent of them relapsed back into addiction after release (Liu 2005). What had made the governance of addiction even more problematic, however, was the realisation from the mid-2000s, the three million drug users who underwent compulsory treatment constituted only a small minority of the actual population of drug users, the number of which remains unknown (Qi 2008). As inmates in policerun drug detoxification centres who relapsed were sent to RETL, RETL institutions became flooded with this new category of detainees and needed to adapt quickly to provide for appropriate drug treatment. Initially such a response came through the establishment of drug rehabilitation quarters (Ministry of Justice Standards on Modern and Civilized Re-Education Through Labour Camps (Xiandaihua Wenming Laojiaosuo Biaozhun) 2004, Article 10). The spread of addiction, particularly among minor offenders, meant that by the late 2000s, a majority of the population of RETL detainees consisted of habitual drug users (Fu 2009). This simple fact, coupled to the rise among the RETL population of drug induced pathologies, such as hepatitis and HIV infections placed an insurmountable strain on the system of RETL and RETL camps which were not well equipped to provide drug treatment and necessary medical care. 
The regulatory basis of RETL, which the Regulations on Public Security Organs Handling Re-Education Through Labour Cases (Gong'an Jiguan Banli Laodong Jiaoyang Anjian Guiding) 2002 had broadened to include conduct that was defined with reference to the Criminal Law 1979 (as amended), was critically out of step with the needs posed by the rapid and steady growth of the addict population within the RETL system. The system appeared flawed not only from a functional and substantive perspective, but from a procedural one as well. Over time, control over the RETL approval procedure had come to be firmly within the hands of the legal division of public security organs. The Regulations on Public Security Organs Handling ReEducation Through Labour Cases 2002 (as amended in 2005) set out procedures to be followed by the public security organs in investigating and determining to impose a period of detention under RETL. These regulations were supplemented by the Regulations on the Procedures for Handling Administrative Cases by Public Security Organs (Gong'an Jiguan Banli Xinzheng Anjian Chengxu Guiding) 2004 (amended in 2006 and 2012) which introduced several improvements in the RETL approval procedure. ${ }^{10}$. However, these regulations failed to challenge the porous boundary between administrative punishment and the criminal law and did not address the inconsistencies between criminal punishment and RETL. Neither did they effectively address the abuses to which the system was prone. If it is considered that by this time addicts were already the majority of RETL population, the procedural reform enacted

\footnotetext{
${ }^{10}$ See also the Regulations on Public Security Organs Handling Re-Education Through Labour Cases (Gong’an Jiguan Banli Laodong Jiaoyang Anjian Guiding) 2002 (amended in 2005), which provided for procedural rules specifically related to RETL. See also the discussion in Biddulph 2007.
} 
in the mid-2000s failed to provide a credible and effective response to the difficulties that the RETL system was facing.

As the domestic and international debate on the abolition of RETL continued, an unexpected, although not unforeseeable, solution came from the National People's Congress, which in 2008 promulgated the People's Republic of China Drug Prohibition Law (Jindu Fa), and from the State's Council enactment, in 2011, of the Drug Prohibition Regulations (Jindu Tiaoli). The Law and the Regulations replaced compulsory drug treatment with a more rational set of custodial and non-custodial measures, which were articulated on three levels. Recreational users, occasional users and habitual users who, if tested positive, could choose to undergo voluntary rehabilitation (ziyuan jiedu) (Drug Prohibition Law, Article 36; Drug Treatment Regulations, Article 11) - a measure which is voluntary and non-custodial - or, alternatively, be ordered to undergo rehabilitation in the community for three years (Drug Prohibition Law, Article 33). Habitual drug users who refused or were ineligible for voluntary rehabilitation became the targets of a new power, compulsory quarantine isolation for drug rehabilitation (qiangzhi geli jiedu) (CQDR), for an initial period of two years, which could be shortened or lengthened by one year (Biddulph and Xie 2011; Drug Prohibition Law, Articles 27, 38, and 43). As with the approval of RETL, the approval procedure of CQDR is among the powers of the police who, after their rehabilitation, can order addicts to receive a period of follow-up treatment in the community (shequ kangfu) for a maximum of three years (Drug Prohibition Law, Article 48). If the person relapses they can receive a further term of compulsory drug rehabilitation (Drug Prohibition Law, Article 38).

Prior to transfer of drug dependent people into CQDR after passage of the Drug Prohibition Law, the RETL system had undergone a deep structural change. In 2004, 
separate quarters were added to RETL facilities to hold those who had received a rehabilitation order. These quarters gradually expanded into drug rehabilitation brigades and squads. Finally, in 2008, on the eve of the promulgation of the Drug Prohibition Law, the closure of the existing police operated drug treatment facilities was ordered. RETL facilities began to expand in order to receive those who had until then been held at drug treatment facilities (Sapio 2010).

If it is considered that, by the mid-2000s, the majority of RETL detainees were in need of drug treatment, the transfer of detainees from compulsory drug treatment centres to RETL facilities meant that by 2013 RETL facilities had, in practice, already been transformed into compulsory drug rehabilitation facilities. As the debate on RETL abolition went on, starting from the end of 2012 local police organs stopped issuing RETL decisions. While it is still not clear whether minor offenders were going unpunished or receiving criminal sanctions, this step signalled the demise of RETL, and its partial replacement by compulsory drug treatment. The abolition of RETL, and the re-designation of some RETL facilities as compulsory drug treatment centres, took place from mid-November 2013.

\section{Reforming Pre-Trial Detention Centres}

In contrast with the dramatic changes described above in relation to administrative detention, neither the legislation nor the institutional structure of pre-trial detention institutions has changed significantly since the early 1990s. As in other areas of the criminal justice system, denunciations of maladministration in pre-trial detention centres and cases of death in custody have brought to light problematic areas in the way pre-trial detention centres are regulated and administered. These injustices have fuelled debates about legislative and institutional reforms. However, to date, proposals 
for reforms have not translated into concrete changes. In the 2000s, attempts to reform the current system have focused on two main areas: first, legislation, in the form of the amendment of the State Council Regulations on Criminal Detention Centres (Kanshousuo Tiaoli) 1990; and secondly, the institution administering pre-trial detention, with the recommendation that authority over pre-trial detention centres be transferred from the MPS to the MoJ. These reform priorities were formalised and publicised in 2009 in the aftermath of the media revelations of the 'hide and seek' (duo mao mao) case (see for example, Liu and Zhang 21 February 2009; Luo 27 February 2009) and a number of other unnatural deaths (feizhengchang siwang) in custody.

Legislative reforms: from the Regulations 1990 to a Detention Centre Law?

In today's PRC, the State Council Regulations on Criminal Detention Centres 1990 and the 1991 Methods of Implementation of the Regulations on Criminal Detention Centres (Kanshousuo Tiaoli De Shishi Banfa) 1991 regulate the work of the police in detention centres as well as the conditions under which detention should be carried out (Nesossi 2012). The 1990 Regulations are supplemented by more than fifty rules, notices and opinions-not counting local legislation-issued by the MPS (sometimes jointly with other ministries, the Supreme People’s Court and the Supreme People's Procuratorate) to regulate all the various aspects of pre-trial detention. The Regulations 1990 have remained untouched ever since their promulgation, and have become obsolete in light of subsequent developments in the criminal justice field and the introduction of new technologies and managerial techniques in places of detention. Adopted well before the promulgation of the Criminal Law 1997, the Criminal Procedure Law 1996, the Police Law (Jingcha Fa) 1995, the Lawyers Law (Lüshi Fa) 1996 (amended in 2007) and other fundamental PRC laws, the Regulations 
1990 often contradict these laws in both spirit and substance. A document of its times, the Regulations 1990 tend to be vague, ambiguous, broadly worded, and replete with (now) outmoded terms and politically laden references. For example, 'criminal' (renfan) is used instead of its contemporary term 'criminal suspect' (fanzui xianyiren), ganjing (colloquialism for police) is used instead of people's police (renmin jingcha), and 'reform through labour' (laodong gaizao) used instead of prison (jianyu).

In March 2000, the Bureau for the Management of Prisons and Criminal Detention Centres of the MPS (Gong'an Bu Jiansuo Guanli Ju) established a small working group (gongzuo xiaozu) for the purpose of reforming the Regulations 1990. All the major justice departments were consulted in the process; such consultation led to a redrafting of the Regulations, with a revised version including 100 articles (compared to the 52 articles in the 1990 version). In December 2008, the plan to reform the Regulations and to strengthen the supervisory role of the procuratorate was officially inserted in the Central Political Committee Opinions on Several Issues on Deepening Reforms of the Judicial System and Working System (Zhongyan Zhengfa Weiyuanhui Guanyu Shenhua Sifa Tizhi He Gongzuo Jizhi Gaige Ruogan Wenti De Yijian) issued by Central Political Committee of the CCP (Cheng 2014, 42). These reform priorities were formalised and made public in 2009 in the aftermath of the 'hide and seek' case. During that year, reforms to the Regulations 1990 were included in the discussion agenda of the State Council and the annual session of the National People Congress (Cheng 2014, 60). While up to that point legislative reform was primarily intended to be an amendment to the Regulations 1990, from then on a number of scholars started to seriously contemplate the option of drafting a new law, the Criminal Detention Law for promulgation by the NPC. On 24 January 2011, the proposal for the amendment of the Regulations on Detention Centres drafted by the MPS was submitted to the State 
Council and, at the time of writing, neither the amendment or the Criminal Detention Law have been passed yet.

Institutional reforms: from the MPS to the MoJ?

In 1983, the MoJ acquired jurisdiction over prisons. On the contrary, pre-trial detention centres remained under the control of the organs of public security. At the time, the Central Political-Legal Committee (zhongyang zhengfa wei) considered whether both prisons and pre-trial detention centres could be transferred to the MoJ, but the idea was soon dismissed. Because of the 'Hard Strike' (yanda) campaign that was on going at the time, the police felt the need to maintain their stronghold on at least one form of criminal detention without having to rely on the newly reestablished MoJ (restored in 1979 after its dissolution during the Maoist period) to facilitate the process of co-ordination between investigation, arrest and detention.

On the whole, the problem of institutional reform relates precisely to the double function given to the public security: that of conducting investigation and, at the same time, detaining individuals. This has meant that places of detention have also become places of investigation, where abusive practices against detainees-like extraction of confession through torture (xingxun bigong)-could be easily condoned or concealed in the guise of obtaining evidence.

Between 2009 and 2010, the national media reported more than ten cases of 'unnatural deaths' in detention facilities, which raised public indignation and fuelled intense debates (China Daily 20 April 2009). At this point in time, scholars and officials from the Ministry of Public Security and the Supreme People's Procuratorate (SPP) were mobilised to make specific suggestions on how to strengthen the existing legal framework of such institutions, improve the conditions for those held within 
detention centres and make places of detention more transparent, through better monitoring and supervision. On 15 April 2009, the MPS held its first ever national meeting focussed on detention supervision since the founding of the PRC; in addition, the MPS and the SPP organised a major investigation on legal implementation in pretrial detention centres, stressing the need to protect the rights and the physical integrity of detainees. On 20 July 2009, the MPS issued the Advice for Further Enhancing and Improving Detention Supervision by Public Security Departments (Guanyu Jin Yi bu Jiaqiang He Gaijin Gong’an Jianguan Gongzuo De Yijian) (Nesossi 2014). From June 2009 to January 2010, the MPS Bureau for the Administration of Prisons and Detention Centres opened up detention centres to external visits and invited media, party officials, members of the NPC, family members, lawyers to visit pre-trial detention centres. Approximately 2100 pre-trial detention centres opened up their doors to external visits in an attempt to enhance a system of transparent operation and strengthen external supervision.

\section{Reforming Prisons}

In comparison to reforms to the system of pre-trial detention and administrative detention, changes to the prison system have attracted less public attention. Calls for reforms have not been widely discussed in the public sphere and have primarily attracted the attention of prison scholars and officials working within the Chinese penitentiary system.

The first Prison Law of the PRC was introduced in 1994. A decade later, scholars and officials involved in prison administration around the country started to debate the inadequacies of such legislation and to put forward proposals for reforms. Reformist voices have been asking for a clearer status assigned to the Prison Law in the Chinese 
legal system. Under scrutiny in these debates is the status of the Law. Critics contend that since the Law 1994 was issued by the NPC Standing Committee and not the NPC itself, the Law may not be considered a 'primary law', that is, on a par with the Criminal Law and the Criminal Procedure Law. Moreover, critics maintain that the Prison Law 1994 is inconsistent in many places with other criminal justice legislation. In addition, it lacks specificity in relation to the rights and duties of police guards, management procedures, financial matters and administration of punishment. In order to strengthen existing legislation, reformers have discussed proposals for supplementary Regulations on Prison Organisation and Regulations on Prison Police, though these proposals have failed to attract significant public attention.

Seven articles of the Prison Law 1994 were revised in October 2012 to make the legislation consistent with the amended Criminal Procedure Law 2012. This revision has not attracted particular attention among scholars or the media. It is considered to be fairly limited in scope and generally unsatisfactory, as it fails to address the main problems in the Law 1994(Han 2013). Prison scholars and officials calling for reforms to the Prison Law 1994 would have hoped that new legislation could also improve the institutional structure of prisons and their relations with other institutions and forms of punishment. They have asked for a better system of supervision, an improved collaboration with the gongjianfa authorities and with governmental authorities at the local level responsible for supporting activities of reform and social reintegration of prisoners (Xie 2009). At the time of writing, this process had not yet begun and reforms appear stalled.

\section{Focusing on Reform in this Volume}


This volume assesses the myriad factors that contribute to reform of detention and incarceration institutions, and examines the related political and social implications of reform. In doing so, it challenges the view that in China the process of reform constitutes a unilateral response to either calls from below or impositions from above. The studies in this book understand 'politics' in the context of reform to be a multifaceted affair. Thus, they ask: what do these dynamics reveal about the nexus existing between law, justice and politics in contemporary China?

Notwithstanding their relevance to the contemporary Chinese system of justice and governance, to date and detailed academic analyses of detention facilities in China have been fairly limited in scope. With the exception of a number of studies on imprisonment and penal policies in traditional China (c.f. Dutton 1992; Dikötter 2002; Mühlhahn 2009), this area of research has been fairly sparse. For many decades, penal policies and the circumstances explaining institutions and conditions of detention have been extremely opaque because of their political sensitivity. The increased openness and transparency in relation to the issue of detention and the paucity of robust academic research related to the experience of deprivation of liberty in the PRC open up opportunities for sustained research in the area. This book aims to address some of the shortcomings in the field by providing a foundation for understanding recent reforms to legal regulations and operation of detention and incarceration facilities with three main focus points. The first relates to administrative punishment; the second concerns the area of criminal justice and the third relates to the scholarly literature on reform. These concerns are the subject of the three main parts in this volume.

Part 1 focuses on administrative detention and punishment. We determined to discuss these topics upfront as these are the areas that, for over 30 years, have been subject to 
sustained public attention and criticism both within and outside China and have been subject to the most dramatic changes. The chapters included here examine the various problematic issues and the challenges concerning recent reforms to China's infamous system of RETL. All the authors here are in favour of a substantial restructuring of the system of administrative detention, but each in their own way, demonstrate different aspects of their scepticism about the feasibility of any revolutionary new reformist attempts to abolish the forms of administrative punishment and non-custodial punishment that have now largely replaced RETL. The ending of RETL raises as many questions as it resolves. While it has been widely celebrated, it is important to note that administration punishment, as a system, has not been abolished. RETL's abolition has shifted the problems characterising the original system of RETL in to different areas of administrative detention. A number of the authors see this problem as inherent to the context of the current legal and institutional structures, which continues to see significant social and political value in punishing illegal behaviour and minor crime outside the auspices of the formal criminal justice system.

Sarah Biddulph's study sets the scene in this initial part of the volume by assessing the meaning and significance of abolishing the system of RETL. The author argues that the ending of RETL has been hailed as a major step toward strengthening both human rights and the rule of law. However, there remains uncertainty about the longterm impact of its abolition on punitive powers more broadly. She points out that in addition to hoped-for improvements in the protection of rights under China's version of the rule of law, there are a number of institutional consequences. One of those has been to transfer the burden and cost of punishment of minor offenders into the criminal justice system and onto local governments and justice agencies who are responsibile for implementing the system of community corrections. 
RETL was abolished without engagement with the broader debates that featured in the years prior to its abolition about the values and priorities the legal system should reflect. Whilst this may not be surprising in view of Party-state's priorities, abolition of RETL does not give any promise that other administrative powers will be reformed in the same way. Instead, the reforms, if any, that might be made to powers such as detention for education of sex workers will depend on their own particular circumstances and a consideration of three core questions. First, is there popular and international criticism of the power such that it can be abolished in a way that is politically advantageous or at least not disadvantageous? Second, can the power be abolished in a way that does not have a significant impact on public order? Finally, is there an alternative available form of punishment, or has there been a decision that this form of punishment no longer needs to be applied to that conduct?

Li Enshen’s chapter delves into the issue of community corrections (shequ jiaozheng) as an alternative to the system of administrative detention. The author combines a detailed analysis of the legislative and institutional frameworks with a socio-political assessment of the difficulties surrounding the implementation of the system of community corrections. He explains that in China today, this burgeoning system lacks sufficient legal justification, social support and financial resources, and crucially, is institutionally inconsistent with China's hukou (household registration) system.

The last chapter in Part 1 by Guo Zhiyuan shifts the lens to a different area of administrative detention. It addresses the system of mental health institutions in contemporary China and the debates related to the enactment of a Mental Health Law in 2012. The author focuses in particular on the problematic issues of involuntary deprivation of liberty and compulsory treatment and she examines relevant legal reforms taking into account both the letter of the law and a number of preliminary 
empirical findings. She concludes by advancing further proposals for reform related to compulsory treatment and involuntary hospitalisation, and by advocating for a change in public attitudes toward psychiatric patients.

Part 2 of this book focuses on other areas of detention in the criminal justice system. It builds on the debates outlined in Part 1 and provides an in-depth analysis of key problematic issues raised by attempts to reform the existing criminal justice system. The focus on detention in this second part of the book covers two key areas where recent controversy has driven reform: residential surveillance and pre-trial detention.

In chapter 5, Joshua Rosenzweig analyses the system of residential surveillance; he considers its scope and the problems raised by its implementation. Rosenzweig places particular emphasis on the debates surrounding residential surveillance in the context of the 2012 amendment of the Criminal Procedure Law. In a similar fashion to other detention practices analysed in this volume, the development of residential surveillance has been influenced significantly by socio-economic changes and crimefighting activities that have been connected with the Party-state's obsession with social and political stability. According to Rosenzweig, residential surveillance was originally intended as a fairly lenient and non-coercive alternative to pre-trial detention, similar to house arrest in western countries. However, over time, it developed in its own right as a distinctive and highly coercive measure. In recent years, both foreign and domestic scholars have voiced their discomfort with the nature and scope of such changes and have found that the public consultation process during the final drafting stage of the 2012 reforms to the CPL was a propitious time to express their concerns and advocate for its abolition. Rosenzweig explains that residential surveillance was indeed substantially revised but retained in the CPL 2012 and today includes two quite distinct measures. The law justifies both an 'ordinary 
form of residential surveillance' intended primarily as a tool for reducing pre-trial detention, and an 'exceptional' non-residential form used to deal with offenders considered by the authorities as serious threats to the socio-political order.

Chapter 6 and 7 are complementary since they examine the system of pre-trial detention, in particular the amendment of the relevant legislation - the 1990 Regulations on Criminal Detention Centres - and the reform of the institution of pretrial detention itself. In chapter 6, Cheng Lei and Elisa Nesossi provide an introduction to the institutional system of pre-trial detention centres. They consider the history, the legislative and institutional framework of Chinese pre-trial detention centres. In addition to offering an insider view on the historical development of the institution, they examine the developments that have occurred in the aftermath of the 'hide and seek' accident that exploded in the media in 2009. They also consider the numerous suggestions for reforms, with a particular focus on the draft of a Criminal Detention Law and the debates surrounding the passage of the authority administering pre-trial detention from the MPS to the MoJ.

Written from the perspective of a scholar and NGO practitioner, Nicola Macbean's chapter considers the factors that have contributed to the crisis of legitimacy facing China's pre-trial detention institutions. In particular, it looks at the recommendations advanced by reformers and the contours of policy response. Macbean argues that various scandals involving brutality and death in custody have brought pre-trial detention institutions to centre stage of the process of reforms. The terms of both legislative and institutional reforms in this area are indeed influenced by imposing human rights principles and laws, overseas practice and greater domestic awareness of the reality of pre-trial detention centres. Macbean argues that the reform process has in part been facilitated by internationally funded pilot projects focussed on specific 
areas like complaints mechanisms, monitoring by the people’s procuratorate and local citizens and improved access to lawyers. By emphasising the urgency of the problems associated with detention, she also claims that the various scandals helped establish within China ideas about minimum standards of treatment in detention and detainees' right to safety. To conclude, she advocates for the creation of a more sophisticated narrative concerning pre-trial detention, one that establishes the rights of the criminal suspects to a presumption of innocence.

Part 3 of the book assesses the question of deprivation of liberty from the point of view of literature and theory.

Chapters 8 and 9 offer an overview of the existing Chinese and western literature on the topic of deprivation of liberty in China. These two chapters analyse respectively key Chinese and western issues and debates in the area and demonstrate that these two academic debates have unfolded in parallel, as two separate discourses and approaches. Elisa Nesossi and Susan Trevaskes (chapter 9) focus on the domestic Chinese literature on imprisonment. They highlight the inevitable link existing between national criminal justice policy, and its impact on institutions of punishment today, and observe how in recent years, new topics, narratives and concepts have emerged and unfolded in the area of prison discourse. Nesossi and Trevaskes trace discursive shifts that reflect new conceptual approaches that have imposed on the system; further, they acknowledge how these are influence by the broader dynamics of change in Chinese politics and society. Their chapter is in two parts. The first discusses the move from Marxist-based discourse of 'reform through labour' in the 1980s and early 1990s to the more legal and penology-focused approaches after the promulgation of the Prison Law 1994. The second part focuses on more recent Chinese literature, surveying a study in a key (practitioner-oriented) specialised 
journal, the Prison Review (Jianyu Pinglun). They select to discuss an exemplar study of the contemporary literature written by three prison officials, that provides an insight into current Chinese thinking about the nature of policy-driven reform that affects both prisoners and the prison system. Nesossi and Trevaskes engage with this 2013 study, to understand the relationship between the country's current 'foundational' criminal justice policy called 'balancing leniency and severity' and recent prison policy and practice.

Flora Sapio’s reflections in chapter 9 discuss the limits of conventional western approaches toward the Chinese correctional system. She explains how these views have generated a 'Gulag narrative' whereby individual depictions of Chinese incarceration have tended to be employed as examples of 'living hell on earth'. Sapio argues that since the early days of the PRC, conventional western narratives have been constructed to create a relatively stereotyped and orientalised image of China and the Chinese, serving political and geo-strategic imperatives. This literature was initially used to justify the imposition of foreign extra-territorial powers at the end of the nineteenth century. Later, it was employed during the Cold War to orientalise the Communist enemy and, since the 1990s, to justify the exportation of human rights values to the authoritarian regime. To mediate such biased and exotic accounts, Sapio advocates a change in perspective - a shift in approach that this volume attempts to realise. Sapio's examination encourages Chinese and Western scholars alike to develop their analysis by exploring this area through the conceptual prisms of criminology and penology, two interpretative grids that may explain the Chinese circumstances in a more discipline-specific way.

Chapter 10, by Nesossi, Biddulph, Sapio and Trevaskes, offers a final reflection on the issues that create opportunities and contribute to define future challenges. The 
chapter concludes by advocating that contemporary scholarship should look critically behind cosmetic changes and understand the deeper forces that drive reforms in China’s contemporary justice system

\section{Conclusion}

Various forms of detention and incarceration belonging to both the criminal justice and administrative systems exist in the PRC to deprive criminal suspects, offenders and wrongdoers of their physical liberty. Social order and stability are primary political concerns in China and it is in this context that detention and imprisonment have become the hallmark of a heavily politicised justice system where crucial political and institutional battles are played out. The studies in this volume develop from the understanding that in China today the Party and the state institutions that control and punish crime remain closely interconnected; this means that law, its implementation and its development are subject to the Party's policy and institutional dominance.

The existing literature in the area of Chinese detention and incarceration indicates that while some of the contemporary forms of detention and incarceration have been widely discussed and explored both domestically and internationally, others remain less well understood. Scholarship on some areas of administration detention such as RETL is highly nuanced and detailed and covers expansive ground. In contrast, there has been very little work outside China on prisons since Seymour and Anderson's work published in the late 1990s. And it was only in the early 2000s that a small number of Chinese scholars and officials began to examine other facilities, such as pre-trial detention centres and to detail the conditions in which prisoners and 
detainees were living. Therefore, it has only been in the last decade or so that many issues concerning detention have been subject to public scrutiny within China, generating calls for reforms. In the process, the legislative authorities have amended some areas of the relevant legislation and established new alternative systems of control.

While scholars have gained more knowledge and access to institutions of detention, to date there has been no sustained study of the recent changes. This volume is the first to centre on the theme of reform to this regime. It is neither intended as a tool to advocate for reforms in the existing detention powers in view of rule of law and human rights principles, nor as an account of what some commentators might see as barbaric punitive practices in China. Written at a time when places of detention are becoming increasingly open, transparent and accessible to external observers, this book is primarily an attempt to explain the complexities in the dynamics of the current process of penal reforms, and the factors which make the need for institutional restructuring in this area both timely and compelling. It does so by bringing together analyses and reflections by both western and Chinese scholars set around the theme of reform over the last decade or more. We expect it to generate an enriching and constructive dialogue about the nature of reform and change in China that was largely absent in earlier studies.

\section{References:}

Alabaster, Ernest, 1899. Notes and Commentaries on Chinese Criminal Law, and Cognate Topics. With special relation to ruling cases. Together with a Brief Excursus 
on The Law of Property, Chiefly Founded on the Writings of the Late Sir Chaloner Alabaster. London: Luzac \& Co.

Balme, Stéphanie and Dowdle. Michael W. eds. 2009. Building Constitutionalism in China. New York: Palgrave Macmillan.

Biddulph, Sarah. 2007. Legal Reform and Administrative Detention Powers in China. Cambridge: Cambridge University Press.

Biddulph, Sarah and Xie Chuanyu. 2011. 'Regulating Drug Dependency in China: The 2008 Drug Rehabilitation Law.' The British Journal of Criminology 51: 978-96.

Biddulph, Sarah. 2012 'Between Rhetoric and Reality: The Use of International Human Rights Norms in Law Reform Debates in China.' In Narrative and Legal Transfers: Informing Law and Development, edited by John Gillespie and Pip Nicholson. Cambridge: Cambridge University Press

Chen Ruihua. 2004. Wei Jue Jiya Zhidu De Shizheng Yanjiu (An Empirical Study of the System of Pre-Trial Detention). Beijing: Beijing daxue chubanshe.

Chen Weidong. 2005. Jiya Zhidu Yu Renquan Baozhang (The System of Detention and Protection of Human Rights). Beijing: Zhongguo jiancha chubanshe.

Cheng Lei. 2014. Kanshousuo Lifa Wenti Yanjiu (On the Legislation About Detention House). Beijing: Zhongguo fazhi chubanshe. 
China Daily. 20 April 2009. 'State Cleans House over Detentions.' http://www.chinadaily.com.cn

Cohen, Jerome A. 1968. The Criminal Process in the People's Republic of China, 1949-63: An Introduction. Cambridge, MA: Harvard University Press.

Commission on Extraterritoriality. 1926. Report of the Commission on Extraterritoriality in China. London: H.M. Stationery Office.

Dikötter, Frank. 2002. Crime, Punishment and the Prison in Modern China. New York: Columbia University Press.

Dutton, Michael R.1992. Policing and Punishment in China: From Patriarchy to the People. Cambridge: Cambridge University Press.

Dutton, Michael. 2005. 'Toward a Government of the Contract: Policing in the Era of Reform.’ In Crime, Punishment and Policing in China, edited by Børge Bakken, 189234. Lanham: Rowman and Littlefield.

Fu Hualing. 2005a. 'Punishing for Profit. Profitability and Rehabilitation in a Laojiao Institution.' In Engaging the Law in China. State, Society, and Possibilities for Justice, edited by Neij J. Diamant, Stanley Lubman and Kevin J. O’Brien, 213-29. Stanford: Stanford University Press. 
Fu Hualing. 2005b. 'Re-Education Through Labor in Historical Perspective.' The China Quarterly 184: 811-31.

Fu Hualing. 2009. 'Dissolving Laojiao.' China Rights Forum 1: 54-8.

Gao Qiang. 21 July 2011. ‘Guowuyuan Jiedu Tiaoli Sui Dabu Chuangxin Dan Xiaoqu Dongtai Guankong Reng Yaoyao Wu (Despite the Big Innovation in the State Council's Drug Prohibition Regulations, Abolition of Dynamic Control is Still Remote).’ http://www.jhak.com/jlzm/zm/2011-07/21/content_6133.html

Guo Chengwei. 2005. Qing Mo Ming Chu Xingsu Fadianhua Yanjiu (Studies on Criminal Procedure Codification at the End of the Qing Dynasty and the Early Period of the Republic of China). Beijing: Zhongguo gong'an daxue chubanshe.

Han Shuqin. 2013. “ “Jianyu Fa” Xiugai Ying Zhu Zhong Jiejue De Ruogan Wenti (Several Major Problems that Needed To Be Solved in the Revision of the Prison Law).’ Henan Sifa Jingguan Zhiye Xueyuan Xuebao (Journal of Henan Judicial Police Vocational College) 11(1): 27-9.

Jeffreys, Elaine. 2004. China, Sex and Prostitution. London: Routledge.

Human Rights Watch. 2002. Dangerous Meditation: China's Campaign Against Falungong. New York, Washington, London, Brussels: Human Rights Watch. 
Liu Jinpeng. 2005. 'You Gao Fuxilü Dui Woguo Xianxing Jiedu Tixi De Sikao (Considering China's Drug Rehabilitation System from the Perspective of the High Relapse Rate).' Fanzui Yu Gaige Yanjiu (Crime and Reform Research) 7: 24.

Liu Ziqian and Zhang Wenling. 21 February 2009. 'Yunnan Jingfang Tongbao Duo Mao Mao Shijian. Cheng Li Wan Youxi Fasheng Yiwai (Yunnan Police Notify about the Accident of Hide and Seek. A Guy Called Li Had an Accident while Playing).' Zhongguo Qingnian Bao (China’s Youth Daily). http://news.sina.com.cn/c/2009-02$\underline{21 / 032717258307 . s h t m l}$.

Lubman, Stanley. 2012. The Evolution of Law Reform in China: An Uncertain Path. Cheltenham: Edward Elgar.

Luo Jieqi. 27 February 2009. 'Guanfang Tongbao ‘Duo Mao Mao’ Shijian Diaocha Jieguo (Officials Notify about the Results of the 'Hide and Seek' Accident).' Caijing. http://www.caijing.com.cn/2009-02-27/110075141.html.

Ma Longhu. 2001. 'Dui Woguo Laodong Jiaoyang Zhidu De Lixing Fenxi (Analysis of the Rationality of My Country's System of Re-Education Through Labour).' Zhengfa Luncong (Collected Essays on Politics and Law) 6: 33-5.

Ministry of Justice. 22 December 2014. 'Zhongguo Jianyu Zuifan Jiaoyu Gaizao Fazhan Qingkuang (The Developmental Trend of Education and Reform of Convicted Offenders in China).' Zhongguo Qingnian Bao (China's Youth Daily). http://www.moj.gov.cn/sfxzjlzx/content/2014-12/22/content_5895340_2.htm. 
Mühlhahn, Klaus. 2009. Criminal Justice in China: A History. Cambridge, MA: Harvard University Press.

Nesossi, Elisa. 2012. China's Pre-Trial Justice: Criminal Justice, Human Rights and Legal Reforms in Contemporary China. London: Wildy, Simmonds and Hill.

Nesossi, Elisa. 2014. 'Detention, Stability and “Social Management Innovation”.' In The Politics of Law and Stability in China, edited by Susan Trevaskes, Elisa Nesossi, Flora Sapio and Sarah Biddulph, 219-43. Cheltenham: Edward Elgar.

Peerenboom, Randall. 2002. China’s Long March toward Rule of Law. Cambridge, New York: Cambridge University Press.

Qi Dan. 2008. Zhi'an Zhixu Guanli Zhuanlun (Special Discussion of the Management of Public Order Administration). Beijing: Zhongguo renmin gong'an daxue chubanshe.

Sapio, Flora. 2010. Sovereign Power and the Law in China. Boston and Leiden: Brill.

Seymour, James D. and Anderson, Richard. 1999. New Ghosts, Old Ghosts. Prison and Labor Reform Camps in China. Armonk: M. E. Sharpe.

Song Yinghui. 2007. Xingshi Susong Fa. Beijing: Tsinghua Daxue chubanshe. 
Star News. 9 March 2015. ‘Xiao Rui: Kanshousuo Boli Gong’an, Yueshu Jingquan Caineng Baozhang Renquan (Xiao Rui: Only by Separating Pretrial Detention Centres from the Police, and Limiting Police Powers Can Human Rights Be Guaranteed).' Sohu. http://star.news.sohu.com/20150309/n409517709.shtml.

Sun Lianzhong. 2007. Xingshi Qiangzhi Cuoshi Yanjiu (Analysis of the Criminal Coercive Measures). Beijing: Zhishi changquan chubanshe.

T’ao Lung-Sheng. 1966. 'Shen Chia-Pen and Modernization of Chinese Law.' Shehui Kexue Luncong (Social Sciences Forum) 25: 275-90.

Woo, Margaret Y.K and Gallagher, Mary E. 2012. Chinese Justice: Civil Dispute Resolution in Contemporary China. Cambridge; New York: Cambridge University Press.

Xie Liping. 2009. 'Guanyu “Jianyufa” Xiugai He Wanshan De Sikao (Reflections on the Revision and Perfection of the "Prison Law”).' Zhongguo Sifa (Justice of China) 2: $23-5$.

Zhang Xuehua. 2005. Xiandai Gong’an Kanshousuo Lingdao Shiwu Quanshu (The Complete Book of Concrete Issues of Contemporary Detention Centres for Public Security Leaders). Tianjin: Tianjin dianzi chubanshe. 


\section{University Library}

\section{- M M I N E R VA A gateway to Melbourne's research publications}

Minerva Access is the Institutional Repository of The University of Melbourne

Author/s:

Nesossi, E;Biddulph, S;Sapio, F;Trevaskes, S

Title:

Legal Reforms and Deprivation of Liberty in Contemporary China

Date:

2016

Citation:

Nesossi, E., Biddulph, S., Sapio, F. \& Trevaskes, S. (2016). Legal Reforms and Deprivation of Liberty in Contemporary China. (1), Routledge.

Persistent Link:

http://hdl.handle.net/11343/252817 